\title{
Effect of Plant Growth Hormones and Liquid Fertilizer on Rooting and Tuberization of Yam (Dioscorea rotundata Poir.) Vine Cuttings
}

\author{
Dibi Konan Evrard Brice1", Kouakou Amani Michel11, Amari Ler-Ogn Dadé Georges Elisée2, \\ Brouth Lorng Jean Bernard ${ }^{2}$, Dossou-Aminon Innocent ${ }^{3}$, Essis Brice Sidoine ${ }^{1}, N^{\prime} z u e ~ B o n i{ }^{1}$, \\ Dick Acka Emmanuel2
}

\author{
${ }^{1}$ Root and Tuber Crops Program, Food Crops Research Station, National Centre for Agronomic Research-CNRA, Bouake, Côte \\ d'Ivoire \\ ${ }^{2}$ Laboratory of Plant Physiology, Biosciences Training and Research Unit, Felix Houphouët-Boigny University, Abidjan, Côte \\ d'Ivoire \\ ${ }^{3}$ Faculty of Science and Technology of Dassa, University of Abomey-Calavi, Abomey-Calavi, Benin \\ Email: *dibikonan@yahoo.fr
}

How to cite this paper: Brice, D.K.E., Michel, K.A., Elisée, A.L.-O.D.G., Bernard, B.L.J., Innocent, D.-A., Sidoine, E.B., Boni, N. and Emmanuel, D.A. (2019) Effect of Plant Growth Hormones and Liquid Fertilizer on Rooting and Tuberization of Yam (Dioscorea rotundata Poir.) Vine Cuttings. American Journal of Plant Sciences, 10, 1903-1920.

https://doi.org/10.4236/ajps.2019.1010134

Received: September 10, 2019

Accepted: October 28, 2019

Published: October 31, 2019

Copyright $\odot 2019$ by author(s) and Scientific Research Publishing Inc. This work is licensed under the Creative Commons Attribution International License (CC BY 4.0).

http://creativecommons.org/licenses/by/4.0/

\begin{abstract}
Vine cutting is an effective solution to solve the problem of seed availability in yam cultivation. This study was conducted to improve the recovery and rooting rate of vine cuttings of Dioscorea rotundata. Two-node cuttings from five (5)-month-old hybrid plants were grown in liquid media consisting of phytohormones ( $\mathrm{AIA}_{3}$ and $\mathrm{GA}_{3}$ ) and liquid fertilizer (NPK 8-8-8) at different concentrations. Observations were made weekly from the 21 st day after transplanting and focused on the survival rate of the cuttings, the number of roots emitted and the number of minitubers initiated. The results obtained showed a significant effect of the different growing media on the survival rate, rooting and production of minitubers. The best survival rates were obtained for cuttings grown in NPK (8-8-8) at $0.25 \%(100 \%)$ and $\mathrm{AIA}_{3}$ at $25 \mathrm{ppm}$ (93.3\%). The highest averages root number was recorded with growing media containing $0.25 \%$ NPK 8-8-8 (20.3) and $25 \mathrm{ppm} \mathrm{AIA}_{3}$ (17.7). Growing media with $0.25 \%$ NPK $(8-8-8)$ and $25 \mathrm{ppm} \mathrm{AIA}_{3}$ provided the highest average numbers of minitubers initiated, respectively 5 and 4.6. Growing medium containing $0.25 \%$ NPK $8-8-8$ has been identified as the one that allows better roots emission and minitubers production by yam vines cuttings.
\end{abstract}

\section{Keywords}

Yam, Vine Cutting, Yam Seed, Growing Medium, Dioscorea rotundata 


\section{Introduction}

Yam (Dioscorea spp.) of the Dioscoreaceae family, is a tuber crop with high nutritional, economic and socio-cultural importance in the tropical world and especially in West Africa where more than $90 \%$ of world production is recorded [1] [2] [3]. In this region of Africa, yam trade accounts for about $32 \%$ of farmers' income [4]. It is a financial source for a significant portion of small producers, especially women, who are mainly involved in production, processing and marketing [5].

In Côte d'Ivoire, yam is the leading food crop with an estimated production of more than 7.148 million tons in 2017 [4]. It is the staple food for more than 56\% of the Ivorian rural population [6]. It is consumed in several forms: boiled, crushed, stewed, roasted and fried. Two species contribute mainly to production: Dioscorea rotundata, a species native to West Africa and Dioscorea alata native to Southeast Asia and introduced into Africa during the 16th century [7] [8] [9].

Yam tubers are intended for two types of use. They can be directly consumed or used as planting material [10]. Yam is mainly vegetatively propagated using whole tubers or different portions of tubers [11] [12]. This vegetative propagation technique has the disadvantage that a significant portion of the harvest is saved as seed for new cultivation [10] [13]. This reduces the proportion of production available for food. On average, it is estimated that $25 \%$ to $50 \%$ of the yam harvest is converted back into seed [12] [14] [15] [16].

The availability and cost of yam seeds have thus been identified as a major limiting factor for the expansion of yam cultivation. Indeed, yam seeds are not only expensive, but also scarce [17]. They represent $40 \%$ to $60 \%$ of the total variable cost of yam production and are also bulky [18] [19] [20]. These constraints are attributed to the relatively low multiplication rate of yams, which varies from 4 to 8 , as opposed to 300 for cereals [21] [22].

In addition, the increase in demographic and land tenure pressure in Côte d'Ivoire is leading to a very high demand for yam seeds [23]. It is, therefore, necessary to reduce the pressure due to the demand for seed on ware yams and to solve the seed shortage caused by the consumption of tubers. Thus, other methods of yam propagation that do not require the use of tubers or a large quantity of tubers are necessary.

Yam vine cuttings to obtain seeds are a promising alternative [12]. This technique has been tested with some success with $D$. alata and $D$. rotundata. Survival rates of $30 \%$ to $80 \%$ and average numbers of minitubers of 0.5 to 2 have been recorded [12] [22] [24]. However, the survival rate, rooting and production of minitubers remain generally low and unstable for $D$. rotundata, the most popular and commercialized species in Africa. These rates have varied from $40 \%$ to $80 \%$ on low soil or carbonized rice husk environments and are not under control [25] [26]. The aeroponics method that gives better results [11] requires the use of advanced equipment that everyone cannot afford. However, a simple nursery phase in a liquid nutrient medium could significantly increase the survival rates of cuttings [27]. To improve the rooting of yam vine cuttings, some works with 
varying results have been carried out using auxins or synthetic hormones [28] [29], natural hormones [30] [31] and inorganic fertilizer [32].

The objective of this study is to develop a simple and effective technique for D. rotundata yams vine cuttings. Specifically, the effect of two types of phytohormones (Indole-3-Acetic Acid and Gibberellic Acid) and a liquid fertilizer (NPK 8-8-8) on the survival rate, rooting and tuberization of vine cuttings are tested.

\section{Materials and Methods}

\subsection{Study Site}

The work was carried out at the Food Crops Research Station (SRCV) of the National Center for Agronomic Research (CNRA) located in Bouake in central Côte d'Ivoire $\left(7^{\circ} 46^{\prime}\right.$ north latitude, $5^{\circ} 06^{\prime}$ west longitude and $376 \mathrm{~m}$ of altitude). The climate in the study area is tropical, humid and bimodal with two rainy seasons (March-June and September-October) and two dry seasons (November February and July-August). The average annual rainfall is between 700 and 1100 $\mathrm{mm}[33]$.

\subsection{Plant Material}

The plant material consisted of vine cuttings of yam hybrids of the species Dioscorea rotundata. The plants are derived from the germination of seeds obtained from intraspecific crossbreeding at the Food Crops Research Station (SRCV).

\subsection{Study Establishment}

The experiment was carried out in a room in $250 \mathrm{ml}$ glass jars placed on a workbench. The jars containing the growing media were arranged in a complete randomized block system with 3 replicates and 37 treatments. The treatments consist of the different liquid growing media tested (Table 1). They are represented by 3 jars containing a medium and constituting the elementary plot. Five (5) cuttings were transplanted per jar, for a total of 15 cuttings per medium (treatment) and per repetition.

The jars were placed in the room under a 12 -hour photoperiod at a temperature between $24^{\circ} \mathrm{C}$ and $28^{\circ} \mathrm{C}$ and a relative humidity between $60 \%$ and $62 \%$.

\subsection{Growing Media}

Hormonal solutions of Indole-3-Acetic Acid $\left(\mathrm{AIA}_{3}\right)$ and Gibberellic Acid $\left(\mathrm{GA}_{3}\right)$ were each prepared at the initial concentration of $100 \mathrm{ppm}$. Daughter solutions of different concentrations: 25; 50 and 75 ppm for $\mathrm{AIA}_{3}$ and 2.5; 5 and $7.5 \mathrm{ppm}$ for $\mathrm{GA}_{3}$ were obtained after diluting the stock solutions in distilled water.

Three doses of a liquid fertilizer NPK (8-8-8) at $0.25 ; 0.50 \%$ and $0.75 \%$ were obtained by diluting $2.5 ; 5$ and $7.5 \mathrm{ml}$ of the fertilizer product in a final volume of 11 distilled water. 
Table 1. Growing media and their composition.

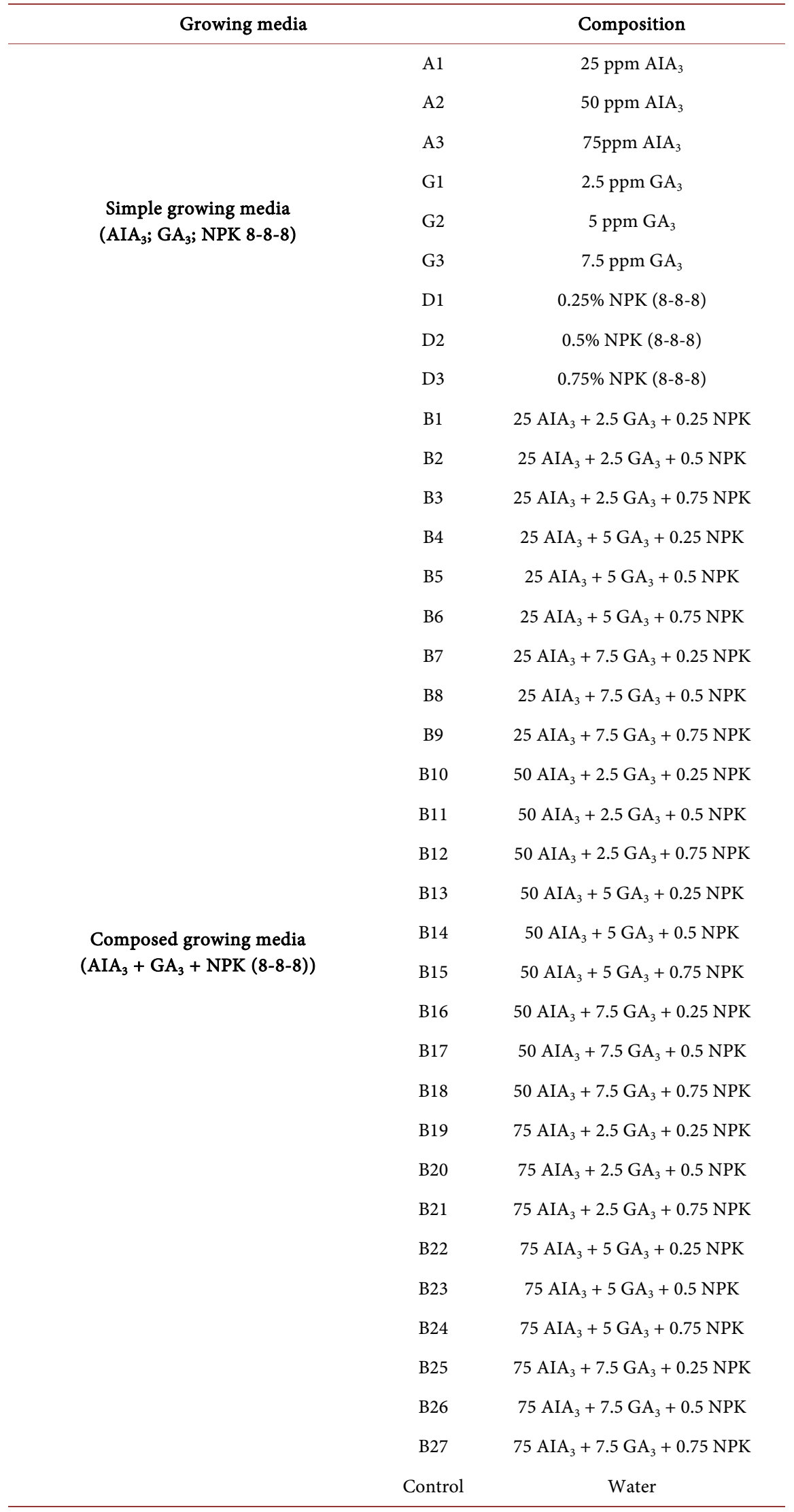


Hormonal solutions (25; 50 and 75 ppm $\mathrm{AIA}_{3} ; 2.5 ; 5$ and 7.5 ppm $\mathrm{GA}_{3}$ ) and doses of NPK $8-8-8(0.25 \% ; 0.50 \%$ and $0.75 \%)$ were put separately in jars to form different simple growing media. Growing media composed of mixtures of the different concentrations of hormonal solutions with the doses of liquid fertilizer, have also been developed. Each jar contained $125 \mathrm{ml}$ of the final growing medium solution (Table 1 ).

\subsection{Sampling, Preparation and Transplanting of Cuttings}

Vine cuttings with two nodes were collected with scissors from five (5) month old yam hybrids of $D$. rotundata growing in a screen house. They were soaked in water during transportation to the growing room to avoid dehydration. Seventy five percent $(75 \%)$ of the cuttings were stripped of their leaves to reduce leaf transpiration. One of the leaves at the top was left in place to allow breathing and photosynthetic activity [34]. The transplanting was carried out by plunging the basal part (basal node) of the cuttings into the different growing media contained in the glass jars.

\subsection{Data Collection}

Observations and measurements were made weekly from the 21 st day after transplanting. They focused on the survival rate of vine cuttings, the number of roots emitted (primary and secondary roots) and the number of minitubers initiated.

\subsection{Statistical Analysis}

The one-factor analysis of variance was performed using STATISTICA version 7.1 software. The Newman-Keuls mean comparison test was applied at the $5 \%$ threshold in cases significant effects were observed between treatments.

\section{Results}

The results recorded concern the survival rate and the number of roots and $\mathrm{mi}$ nitubers initiated by vine cuttings in the different growing media (Figure 1).

\subsection{Effects of Different Growing Media on the Survival Rate of Cuttings}

For media containing $\mathrm{AIA}_{3}$ (Figure 2), the highest survival rate value was $93.3 \%$. It was recorded with the growing medium containing the lowest concentration of $\mathrm{AIA}_{3}(\mathrm{~A} 1=25 \mathrm{ppm})$. This rate is significantly different $(\mathrm{p}=0.00)$ from those recorded with media with concentrations (A2 and A3) of $0 ; 50$ and 75 ppm $\mathrm{AIA}_{3}$. For these concentrations, the exercise rates are $40 \%, 73.3 \%$ and $60 \%$ respectively. No significant differences were noted between media at 50 and $75 \mathrm{ppm} \mathrm{AIA}_{3}$.

The highest average survival rate for $\mathrm{GA}_{3}$-based media was $60 \%$ (Figure 3 ). It was obtained with the lowest concentration (G1) which is $2.5 \mathrm{ppm}$. This survival rate is about the double and significantly different $(\mathrm{p}=0.00)$ from those of cut- 
tings grown in media (G2 and G3) containing 5 and $7.5 \mathrm{ppm} \mathrm{GA}_{3}$ as well as in the control medium containing only water $(\mathrm{C})$.

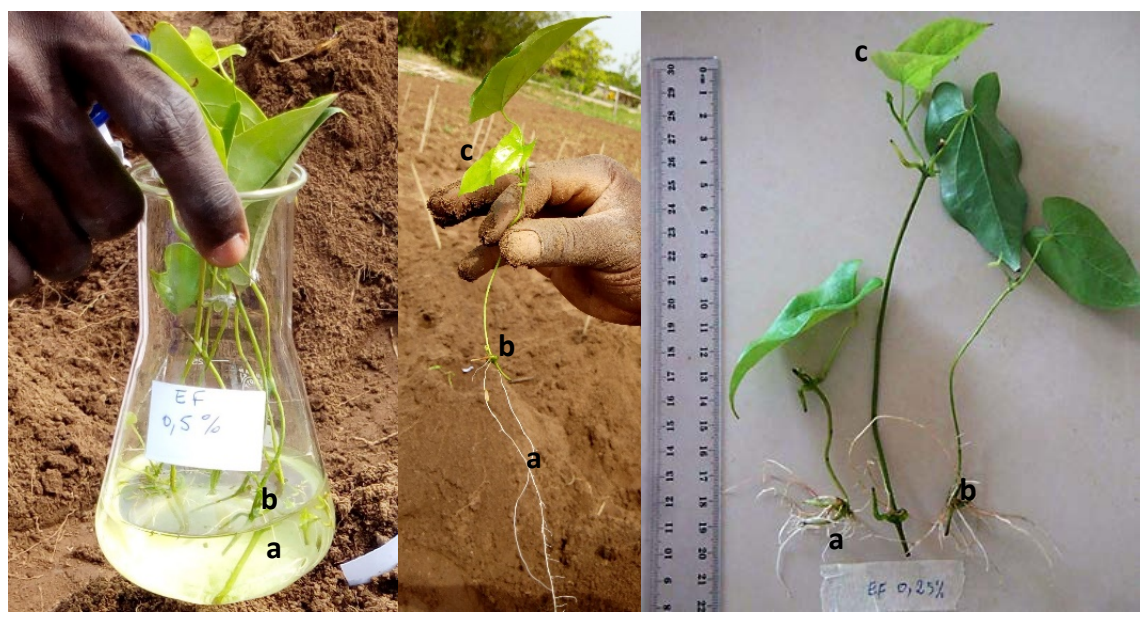

Figure 1. Vine cuttings growing in a liquid media in a jar with roots and minitubers initiated. a: Roots; b: minituber initiated; c: new leaf generated.

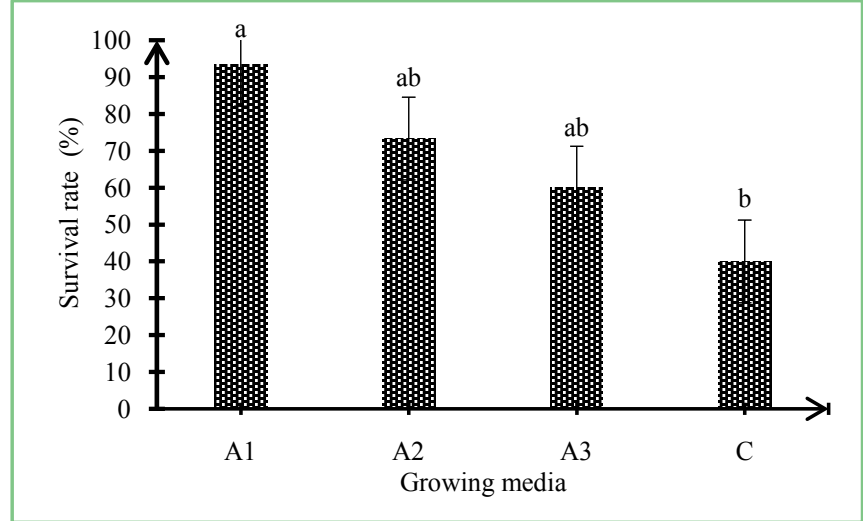

Figure 2. Survival rate of vine cuttings in growing media containing different concentrations of indole-3-acetic acid $\left(\mathrm{AIA}_{3}\right)$. A1: $25 \mathrm{ppm}$; A2: 50 ppm; A3: 75 ppm; C: Control (water).

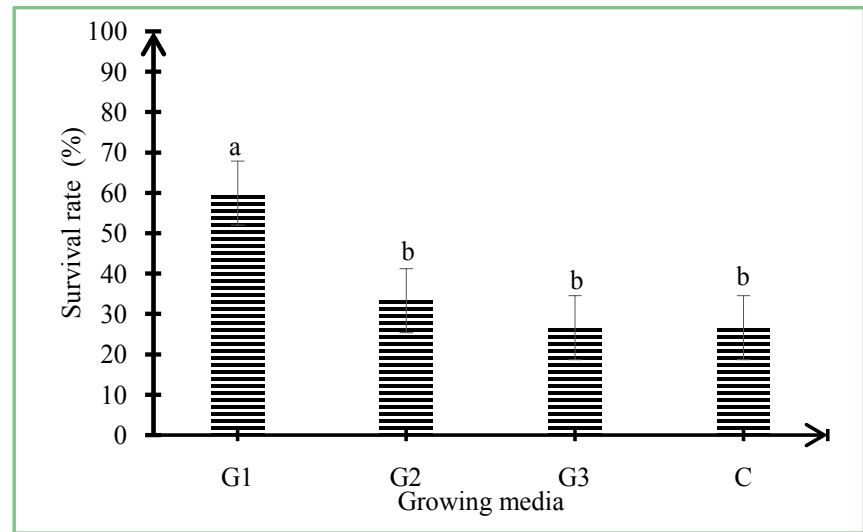

Figure 3. Survival rate of vine cuttings in growing media containing different concentrations of gibberellic acid $\left(\mathrm{GA}_{3}\right)$. G1: 2.5 ppm; G2: 5 ppm; G3: 7.5 ppm; C: Control (water). 
For media containing liquid fertilizer NPK 8-8-8 (Figure 4), a significant effect $(p=0.01)$ was also observed between them. The lowest dose of liquid fertilizer (D1) of $0.25 \%$ resulted in a $100 \%$ survival rate. With media D2 and D3 containing $0.5 \%$ and $0.75 \%$ respectively, the survival rates were lower $(60 \%)$.

The average survival rates of cuttings are significantly different in growing media composed of combinations of hormonal solutions ( $\mathrm{AIA}_{3}$ and $\mathrm{GA}_{3}$ ) and liquid fertilizer NPK 8-8-8 (Table 2). Growing media B2 (25 ppm AIA $3+5$ ppm $\left.\mathrm{GA}_{3}+0.5 \% \mathrm{NPK}\right), \mathrm{B} 11$ (50 ppm $\left.\mathrm{AIA}_{3}+2.5 \mathrm{ppm} \mathrm{GA}+0.5 \% \mathrm{NPK} 8-8-8\right)$ and B22 (75 ppm $\mathrm{AIA}_{3}+5$ ppm GA $3+0.25 \%$ NPK 8-8-8) showed the highest survival rates of $66.6 \% ; 62.4 \%$ and $60.0 \%$ respectively.

\subsection{Effects of Different Growing Media on Root Emission of Cuttings}

The average number of roots assessed 21 days after transplanting the cuttings was higher (11.7) with the medium containing the lowest dose of $\mathrm{AIA}_{3}$ (Figure 5) which was $25 \mathrm{ppm}$ (A1). At this date, treatments A2 (50 ppm AIA $)$, A3 (75 ppm $\left.\mathrm{AIA}_{3}\right)$ and the control $(\mathrm{C}=$ without auxin) have induced 6,4 and 3.3 roots per cuttings respectively. Subsequently, root numbers increased in all media. The values recorded 35 days after transplanting the cuttings were 17.7, 14, 10.3 and 6.7 respectively for growing media $\mathrm{A} 1, \mathrm{~A} 2, \mathrm{~A} 3$ and the control.

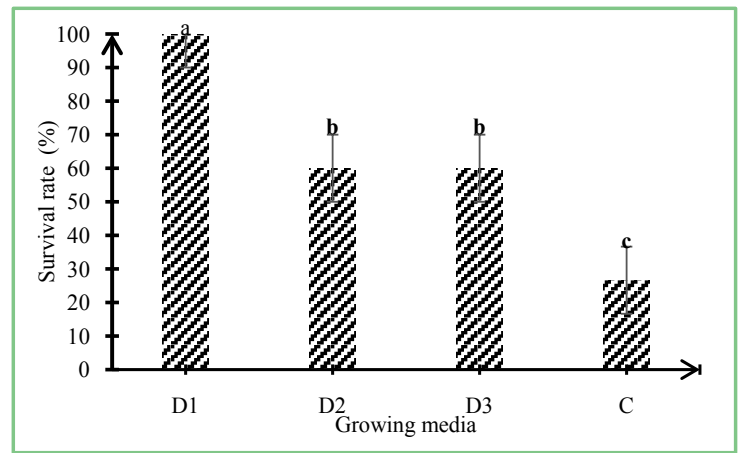

Figure 4. Survival rate of vine cuttings in growing media containing different concentrations of liquid fertilizer (NPK 8-8-8). D1: 0.25\%; D2: 0.5\%; D3: 0.75\%; C: Control (water).

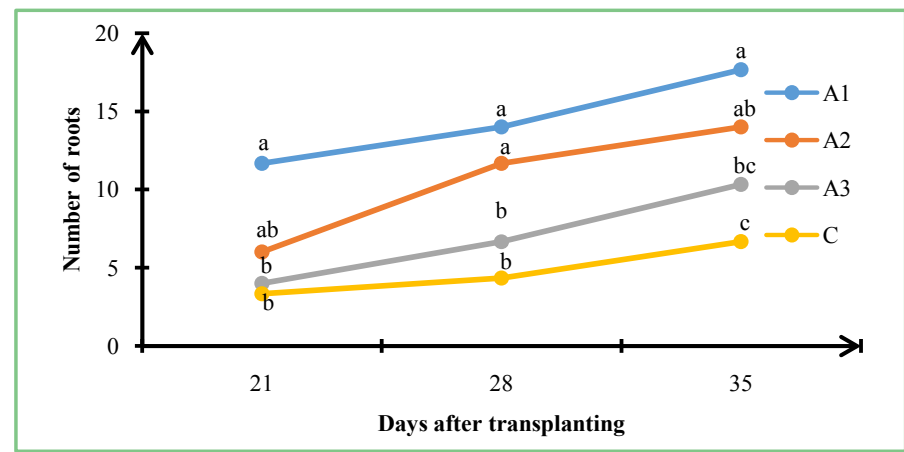

Figure 5. Root emission of vine cuttings in growing media containing different concentrations of indole-3-acetic acid $\left(\mathrm{AIA}_{3}\right)$. A1: 25 ppm; A2: 50 ppm; A3: 75 ppm; C: Control (water). 
Table 2. Survival rates means of vine cuttings in growing media consisting of mixtures of hormonal solutions ( $\mathrm{AIA}_{3}$ and $\mathrm{GA}_{3}$ ) and liquid fertilizer (NPK 8-8-8).

\begin{tabular}{|c|c|c|}
\hline Growing media & Composition & Survival rates means (\%) \\
\hline B1 & $25 \mathrm{AIA}_{3}+2.5 \mathrm{GA}_{3}+0.25 \mathrm{NPK}$ & $0.0 \mathrm{e}$ \\
\hline B2 & $25 \mathrm{AIA}_{3}+2.5 \mathrm{GA}_{3}+0.5 \mathrm{NPK}$ & $66.6 \mathrm{a}$ \\
\hline B3 & $25 \mathrm{AIA}_{3}+2.5 \mathrm{GA}_{3}+0.75 \mathrm{NPK}$ & $40.0 \mathrm{~b}$ \\
\hline B4 & $25 \mathrm{AIA}_{3}+5 \mathrm{GA}_{3}+0.25 \mathrm{NPK}$ & $33.3 \mathrm{~b}$ \\
\hline B5 & $25 \mathrm{AIA}_{3}+5 \mathrm{GA}_{3}+0.5 \mathrm{NPK}$ & $26.6 \mathrm{bcde}$ \\
\hline B6 & $25 \mathrm{AIA}_{3}+5 \mathrm{GA}_{3}+0.75 \mathrm{NPK}$ & $26.6 \mathrm{bcde}$ \\
\hline B7 & $25 \mathrm{AIA}_{3}+7.5 \mathrm{GA}_{3}+0.25 \mathrm{NPK}$ & $26.6 \mathrm{bcde}$ \\
\hline B8 & $25 \mathrm{AIA}_{3}+7.5 \mathrm{GA}_{3}+0.5 \mathrm{NPK}$ & $40.0 \mathrm{~b}$ \\
\hline B9 & $25 \mathrm{AIA}_{3}+7.5 \mathrm{GA}_{3}+0.75 \mathrm{NPK}$ & $20.0 \mathrm{bcde}$ \\
\hline B10 & $50 \mathrm{AIA}_{3}+2.5 \mathrm{GA}_{3}+0.25 \mathrm{NPK}$ & $10.0 \mathrm{cde}$ \\
\hline B11 & $50 \mathrm{AIA}_{3}+2.5 \mathrm{GA}_{3}+0.5 \mathrm{NPK}$ & $62.4 \mathrm{a}$ \\
\hline B12 & $50 \mathrm{AIA}_{3}+2.5 \mathrm{GA}_{3}+0.75 \mathrm{NPK}$ & $20.0 \mathrm{bcde}$ \\
\hline B13 & $50 \mathrm{AIA}_{3}+5 \mathrm{GA}_{3}+0.25 \mathrm{NPK}$ & $26.6 \mathrm{bcde}$ \\
\hline B14 & $50 \mathrm{AIA}_{3}+5 \mathrm{GA}_{3}+0.5 \mathrm{NPK}$ & $20.0 \mathrm{bcde}$ \\
\hline B15 & $50 \mathrm{AIA}_{3}+5 \mathrm{GA}_{3}+0.75 \mathrm{NPK}$ & $6.6 \mathrm{cde}$ \\
\hline B16 & $50 \mathrm{AIA} 3+7.5 \mathrm{GA} 3+0.25 \mathrm{NPK}$ & $20.0 \mathrm{bcde}$ \\
\hline B17 & $50 \mathrm{AIA}_{3}+7.5 \mathrm{GA}_{3}+0.5 \mathrm{NPK}$ & $14.0 \mathrm{bcde}$ \\
\hline B18 & $50 \mathrm{AIA}_{3}+7.5 \mathrm{GA}_{3}+0.75 \mathrm{NPK}$ & $0.0 \mathrm{e}$ \\
\hline B19 & $75 \mathrm{AIA}_{3}+2.5 \mathrm{GA}_{3}+0.25 \mathrm{NPK}$ & $13.3 \mathrm{bcde}$ \\
\hline B20 & $75 \mathrm{AIA}_{3}+2.5 \mathrm{GA}_{3}+0.5 \mathrm{NPK}$ & $20.0 \mathrm{bcde}$ \\
\hline B21 & $75 \mathrm{AIA}_{3}+2.5 \mathrm{GA}_{3}+0.75 \mathrm{NPK}$ & $20.0 \mathrm{bcde}$ \\
\hline B22 & $75 \mathrm{AIA}_{3}+5 \mathrm{GA}_{3}+0.25 \mathrm{NPK}$ & $60.0 \mathrm{a}$ \\
\hline B23 & $75 \mathrm{AIA}_{3}+5 \mathrm{GA}_{3}+0.5 \mathrm{NPK}$ & $26.6 \mathrm{bcde}$ \\
\hline B24 & $75 \mathrm{AIA}_{3}+5 \mathrm{GA}_{3}+0.75 \mathrm{NPK}$ & $20.0 \mathrm{bcde}$ \\
\hline B25 & $75 \mathrm{AIA}_{3}+7.5 \mathrm{GA}_{3}+0.25 \mathrm{NPK}$ & $20.0 \mathrm{bcde}$ \\
\hline B26 & $75 \mathrm{AIA}_{3}+7.5 \mathrm{GA}_{3}+0.5 \mathrm{NPK}$ & $20.0 \mathrm{bcde}$ \\
\hline B27 & $75 \mathrm{AIA}_{3}+7.5 \mathrm{GA}_{3}+0.75 \mathrm{NPK}$ & $20.0 \mathrm{bcde}$ \\
\hline Control & Water & $26.6 \mathrm{bcde}$ \\
\hline$P$-value & & 0.00 \\
\hline
\end{tabular}

Survival rates means followed by the same letter in a column are not significantly different at a probability threshold of $5 \%$, according to the Newman-Keuls mean comparison test.

The growing medium with the lowest concentration of gibberellin G1 (2.5 ppm of $\mathrm{GA}_{3}$ ) and the control medium without this hormone induced the highest mean root numbers (Figure 6). For these media, the values increased from 5.3 and 4 respectively on the 21 st day after transplanting the cuttings to 6.3 on the 35th day. In other respects, the lowest average numbers of roots emitted by yam cuttings were recorded in the case of G2 (5 ppm of GA $)$ and G3 (7.5 ppm of 
$\mathrm{GA}_{3}$ ) treatments. For the latter media, the values ranged from 2.7 to 4 and 1.3 to 3 roots on average from day 21 to day 35 after transplanting.

Between the 21st and 35th days after transplanting the cuttings, the average number of roots formed varied from 12 to 20.3 in medium D1 (0.25\% NPK) and from 9.3 to 17.7 on average in medium D2 (0.5\% NPK) and D3 (0.75\% NPK). The average number of roots of cuttings in water (control) increased from 4 to 6.3 (Figure 7).

For the combination of the 3 products, 21 days after transplanting, yam vine cuttings emitted a greater number of roots in $\mathrm{B} 2$ medium (25 ppm $\mathrm{AIA}_{3}+2.5$ ppm $\mathrm{GA}_{3}+0.5 \%$ NPK 8-8-8) than in other combined media (Table 3). However, on average 7.5 and 6.5 roots were emitted by the cuttings respectively in the media B11 (50 ppm AIA $3+2.5$ ppm GA $3+0.5 \%$ NPK 8-8-8) and B22 (75 ppm $\mathrm{AIA}_{3}+5 \mathrm{ppm} \mathrm{GA}+0.25 \%$ NPK 8-8-8). On the thirty-fifth day after transplanting, the highest numbers of roots emitted by cuttings were 16.5 in $\mathrm{B} 2$ medium (25 ppm $\left.\mathrm{AIA}_{3}+2.5 \mathrm{ppm} \mathrm{GA}+0.5 \% \mathrm{NPK} 8-8-8\right)$ and 9.5 in B3 medium

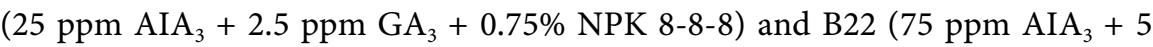
ppm $\mathrm{GA}_{3}+0.25 \%$ NPK 8-8-8).

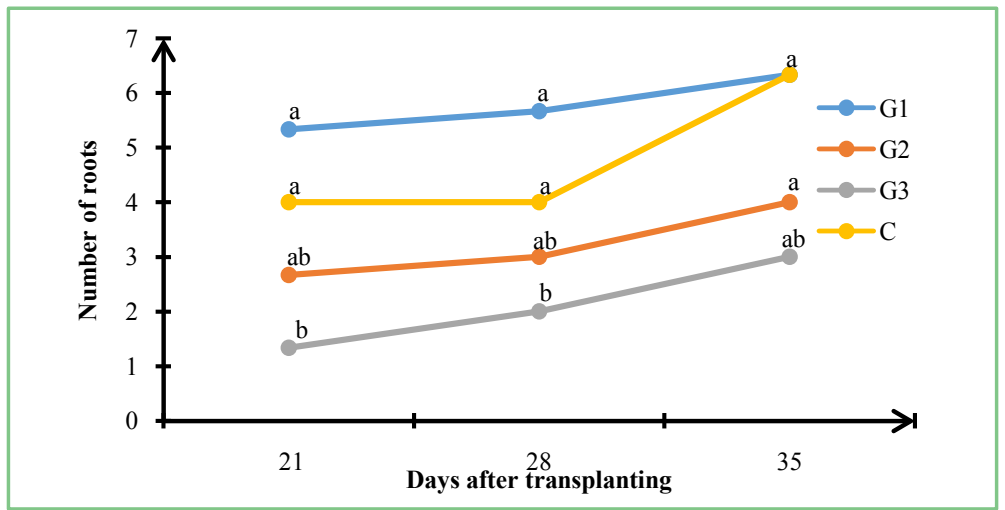

Figure 6. Root emission of vine cuttings in growing media containing different concentrations of gibberellic acid $\left(\mathrm{GA}_{3}\right)$. G1: 2.5 ppm; G2: 5 ppm; G3: 7.5 ppm; C: Control (water).

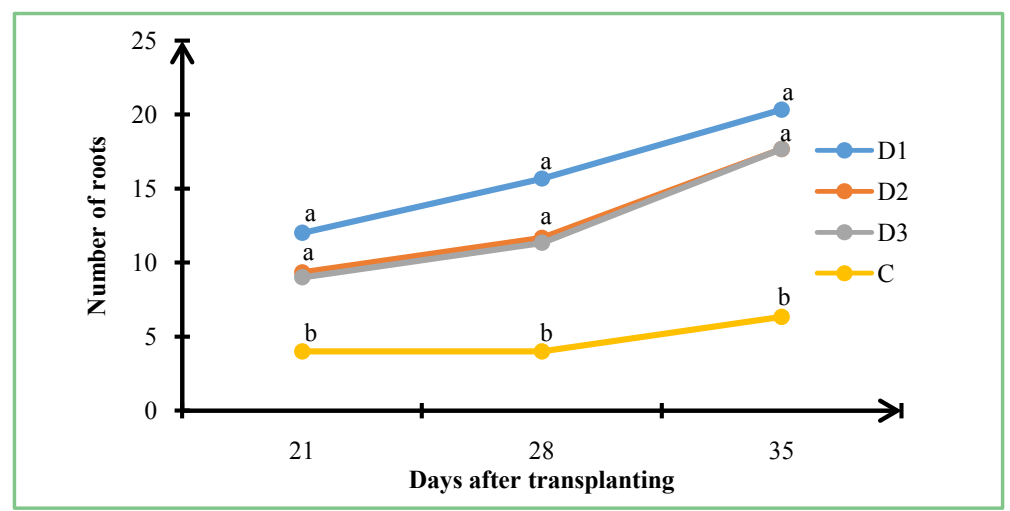

Figure 7. Root emission of vine cuttings in growing media containing different concentrations of liquid fertilizer (NPK 8-8-8). D1: 0.25\%; D2: 0.5\%; D3: $0.75 \%$; C: Control (water). 
Table 3. Roots numbers means observed on yam vine cuttings at different dates after transplanting into growing media consisting of mixtures of hormonal solutions $\left(\mathrm{AIA}_{3}\right.$ and $\mathrm{GA}_{3}$ ) and liquid fertilizer (NPK 8-8-8).

\begin{tabular}{|c|c|c|c|c|}
\hline \multirow{3}{*}{ Growing media } & \multirow{3}{*}{ Compositions } & \multirow{2}{*}{\multicolumn{3}{|c|}{$\begin{array}{c}\text { Number of roots } \\
\text { Days after transplanting }\end{array}$}} \\
\hline & & & & \\
\hline & & 21 & 28 & 35 \\
\hline B1 & $25 \mathrm{AIA}_{3}+2.5 \mathrm{GA}_{3}+0.25 \mathrm{NPK}$ & $0.0 \mathrm{c}$ & $0.0 \mathrm{c}$ & $0.0 \mathrm{c}$ \\
\hline B2 & $25 \mathrm{AIA}_{3}+2.5 \mathrm{GA}_{3}+0.5 \mathrm{NPK}$ & $9.5 \mathrm{a}$ & $13 \mathrm{a}$ & $16.5 \mathrm{a}$ \\
\hline B3 & $25 \mathrm{AIA}_{3}+2.5 \mathrm{GA}_{3}+0.75 \mathrm{NPK}$ & $4.5 \mathrm{abc}$ & $7 \mathrm{ab}$ & $9.5 \mathrm{ab}$ \\
\hline B4 & $25 \mathrm{AIA}_{3}+5 \mathrm{GA}_{3}+0.25 \mathrm{NPK}$ & $0.5 \mathrm{c}$ & $0.5 \mathrm{c}$ & $1.0 \mathrm{c}$ \\
\hline B5 & $25 \mathrm{AIA}_{3}+5 \mathrm{GA}_{3}+0.5 \mathrm{NPK}$ & $0.0 \mathrm{c}$ & $2.0 \mathrm{bc}$ & $2.0 \mathrm{bc}$ \\
\hline B6 & $25 \mathrm{AIA}_{3}+5 \mathrm{GA}_{3}+0.75 \mathrm{NPK}$ & $4.0 \mathrm{abc}$ & $5.5 \mathrm{ab}$ & $9.5 \mathrm{ab}$ \\
\hline B7 & $25 \mathrm{AIA}_{3}+7.5 \mathrm{GA}_{3}+0.25 \mathrm{NPK}$ & $0.0 \mathrm{c}$ & $0.5 \mathrm{c}$ & $0.5 \mathrm{c}$ \\
\hline B8 & $25 \mathrm{AIA}_{3}+7.5 \mathrm{GA}_{3}+0.5 \mathrm{NPK}$ & $0.0 \mathrm{c}$ & $0.0 \mathrm{c}$ & $0.0 \mathrm{c}$ \\
\hline B9 & $25 \mathrm{AIA}_{3}+7.5 \mathrm{GA}_{3}+0.75 \mathrm{NPK}$ & $1.5 \mathrm{bc}$ & $3.5 \mathrm{abc}$ & $5 \mathrm{abc}$ \\
\hline B10 & $50 \mathrm{AIA}_{3}+2.5 \mathrm{GA}_{3}+0.25 \mathrm{NPK}$ & $0.0 \mathrm{c}$ & $2.5 \mathrm{abc}$ & $2.5 b c$ \\
\hline B11 & $50 \mathrm{AIA}_{3}+2.5 \mathrm{GA}_{3}+0.5 \mathrm{NPK}$ & $7.5 \mathrm{ab}$ & $8.5 \mathrm{ab}$ & $9.0 \mathrm{ab}$ \\
\hline B12 & $50 \mathrm{AIA}_{3}+2.5 \mathrm{GA}_{3}+0.75 \mathrm{NPK}$ & $0.5 \mathrm{c}$ & $1.0 \mathrm{bc}$ & $1.5 \mathrm{c}$ \\
\hline B13 & $50 \mathrm{AIA}_{3}+5 \mathrm{GA}_{3}+0.25 \mathrm{NPK}$ & $1.0 \mathrm{bc}$ & $5.5 \mathrm{abc}$ & $6.5 \mathrm{ab}$ \\
\hline B14 & $50 \mathrm{AIA}_{3}+5 \mathrm{GA}_{3}+0.5 \mathrm{NPK}$ & $4.0 \mathrm{abc}$ & $4.0 \mathrm{abc}$ & $5.0 \mathrm{abc}$ \\
\hline B15 & $50 \mathrm{AIA}_{3}+5 \mathrm{GA}_{3}+0.75 \mathrm{NPK}$ & $0.0 \mathrm{c}$ & $0.0 \mathrm{c}$ & $0.0 \mathrm{c}$ \\
\hline B16 & $50 \mathrm{AIA}_{3}+7.5 \mathrm{GA}_{3}+0.25 \mathrm{NPK}$ & $0.0 \mathrm{c}$ & $0.0 \mathrm{c}$ & $0.0 \mathrm{c}$ \\
\hline B17 & $50 \mathrm{AIA}_{3}+7.5 \mathrm{GA}_{3}+0.5 \mathrm{NPK}$ & $6.0 \mathrm{ab}$ & $6.5 \mathrm{ab}$ & $6.5 \mathrm{ab}$ \\
\hline B18 & $50 \mathrm{AIA}_{3}+7.5 \mathrm{GA}_{3}+0.75 \mathrm{NPK}$ & $0.0 \mathrm{c}$ & $0.0 \mathrm{c}$ & $0.0 \mathrm{c}$ \\
\hline B19 & $75 \mathrm{AIA}_{3}+2.5 \mathrm{GA}_{3}+0.25 \mathrm{NPK}$ & $0.0 \mathrm{c}$ & $0.0 \mathrm{c}$ & $0.0 \mathrm{c}$ \\
\hline B20 & $75 \mathrm{AIA}_{3}+2.5 \mathrm{GA}_{3}+0.5 \mathrm{NPK}$ & $1.5 \mathrm{bc}$ & $2.5 \mathrm{bc}$ & $4.0 \mathrm{abc}$ \\
\hline B21 & $75 \mathrm{AIA}_{3}+2.5 \mathrm{GA}_{3}+0.75 \mathrm{NPK}$ & $0.0 \mathrm{c}$ & $5.5 \mathrm{abc}$ & $5.5 \mathrm{abc}$ \\
\hline B22 & $75 \mathrm{AIA}_{3}+5 \mathrm{GA}_{3}+0.25 \mathrm{NPK}$ & $6.5 \mathrm{ab}$ & $9.0 \mathrm{a}$ & $9.5 \mathrm{ab}$ \\
\hline B23 & $75 \mathrm{AIA}_{3}+5 \mathrm{GA}_{3}+0.5 \mathrm{NPK}$ & $0.5 \mathrm{c}$ & $0.5 \mathrm{c}$ & $0.5 \mathrm{c}$ \\
\hline B24 & $75 \mathrm{AIA}_{3}+5 \mathrm{GA}_{3}+0.75 \mathrm{NPK}$ & $2.0 \mathrm{bc}$ & $2.5 \mathrm{bc}$ & $3.5 b c$ \\
\hline B25 & $75 \mathrm{AIA}_{3}+7.5 \mathrm{GA}_{3}+0.25 \mathrm{NPK}$ & $0.0 \mathrm{c}$ & $2 b c$ & $2.0 \mathrm{bc}$ \\
\hline B26 & $75 \mathrm{AIA}_{3}+7.5 \mathrm{GA}_{3}+0.5 \mathrm{NPK}$ & $0.0 \mathrm{c}$ & $0.5 \mathrm{c}$ & $0.5 \mathrm{bc}$ \\
\hline B27 & $75 \mathrm{AIA}_{3}+7.5 \mathrm{GA}_{3}+0.75 \mathrm{NPK}$ & $2.5 \mathrm{bc}$ & $4.5 \mathrm{abc}$ & $7.0 \mathrm{ab}$ \\
\hline Control & Water & $5.5 \mathrm{abc}$ & $6 a b$ & 7.5ab \\
\hline$P$-value & 0.0 & & & \\
\hline
\end{tabular}

Roots numbers means followed by the same letter in a column are not significantly different at a probability threshold of $5 \%$, according to the Newman-Keuls mean comparison test. 


\subsection{Effects of Different Growing Media on the Number of Minitubers Initiated}

Cuttings transplanted into growing media containing 25 and $50 \mathrm{ppm}$ of $\mathrm{AIA}_{3}$ initiated on average 4.6 and 3.6 minitubers respectively (Table 4 ). These numbers of minitubers are the double of those initiated in growing media containing 75 ppm $\mathrm{AIA}_{3}$ and in the control medium.

On media containing $\mathrm{GA}_{3}$, there was no significant difference for the production of minitubers (Table 5). Indeed, cuttings grown in media containing 2.5 and $5 \mathrm{ppm}$ of $\mathrm{GA}_{3}$ produced an average of one (01) minitubert. Cuttings grown in the medium containing 7.5 ppm $\mathrm{GA}_{3}$ and in the control medium did not produce any minituber.

The average numbers of minitubers produced by the cuttings are significantly different between growing media containing different doses of liquid fertilizer (Table 6). The largest numbers of minitubers were produced in media D1 at $0.25 \%$ NPK $(5.0 \pm 0.0)$ and D3 at $0.75 \%$ NPK $(4.0 \pm 1.1)$. Cuttings grown in medium D2 containing $0.5 \%$ NPK produced an average of $3.3 \pm 0.3$ minitubers. The cuttings did not produce any minitubers in the water control medium.

A significant difference ( $\mathrm{p}=0.00$ ) is noted between the different growing media containing a mixture of the three (3) types of elements (Table 7). The average number of minitubers $(3.0 \pm 0.0)$ obtained in $\mathrm{B} 2$ medium $\left(25 \mathrm{ppm} \mathrm{AIA}_{3}+\right.$ 2.5 ppm $\mathrm{GA}_{3}+0.5 \%$ NPK 8-8-8) was the highest. The cuttings transplanted into the $\mathrm{B} 6$ medium (25 ppm $\mathrm{AIA}_{3}+5 \mathrm{ppm} \mathrm{GA}_{3}+0.75 \%$ NPK 8-8-8), had an average number of minitubers of $2.0 \pm 0.5$. The other combinations of media produced one or no minitubers.

Table 4. Number of minitubers initiated by vine cuttings in growing media containing different concentrations of indole-3-acetic acid ( $\left.\mathrm{AIA}_{3}\right)$.

\begin{tabular}{ccc}
\hline Growing media & Compositions & Number of minitubers initiated \\
\hline A1 & $25 \mathrm{ppm} \mathrm{AIA}_{3}$ & $4.6 \pm 0.3 \mathrm{a}$ \\
A2 & $50 \mathrm{ppm} \mathrm{AIA}_{3}$ & $3.6 \pm 0.6 \mathrm{a}$ \\
A3 & $75 \mathrm{ppm} \mathrm{AIA}$ & $1,6 \pm 0.3 \mathrm{~b}$ \\
Control & water & $0.0 \pm 0.0 \mathrm{~b}$ \\
$P$-value & & 0.00 \\
\hline
\end{tabular}

Minitubers numbers means followed by the same letter in a column are not significantly different at a probability threshold of $5 \%$, according to the Newman-Keuls mean comparison test.

Table 5. Number of minitubers initiated by vine cuttings in growing media containing different concentrations of gibberellic acid $\left(\mathrm{GA}_{3}\right)$.

\begin{tabular}{ccc}
\hline Growing media & Compositions & Number of minitubers initiated \\
\hline G1 & $2.5 \mathrm{ppm} \mathrm{GA}_{3}$ & $1.0 \pm 0.0 \mathrm{a}$ \\
G2 & $5 \mathrm{ppm} \mathrm{GA}_{3}$ & $1.0 \pm 0.0 \mathrm{a}$ \\
G3 & $7.5 \mathrm{ppm} \mathrm{GA}$ & $0.0 \pm 0.0 \mathrm{a}$ \\
Control & water & $0.0 \pm 0.0 \mathrm{a}$ \\
$P$-value & & 0.1 \\
\hline
\end{tabular}

Minitubers numbers means followed by the same letter in a column are not significantly different at a probability threshold of 5\%, according to the Newman-Keuls mean comparison test. 
Table 6. Number of minitubers initiated by vine cuttings in growing media containing different concentrations of liquid fertilizer (NPK 8-8-8).

\begin{tabular}{ccc}
\hline Growing media & Compositions & Number of minitubers initiated \\
\hline D1 & $0.25 \% \mathrm{NPK}$ & $5.0 \pm 0.0 \mathrm{a}$ \\
D2 & $0.5 \% \mathrm{NPK}$ & $3.3 \pm 0.3 \mathrm{ab}$ \\
D3 & $0.75 \% \mathrm{NPK}$ & $4.0 \pm 1.1 \mathrm{a}$ \\
Control & water & $0.0 \pm 0.0 \mathrm{~b}$ \\
$P$-value & & 0.01 \\
\hline
\end{tabular}

Minitubers numbers means followed by the same letter in a column are not significantly different at a probability threshold of 5\%, according to the Newman-Keuls mean comparison test.

Table 7. Number of minitubers initiated by vine cuttings in growing media consisting of mixtures of hormonal solutions ( $\mathrm{AIA}_{3}$ and $\mathrm{GA}_{3}$ ) and liquid fertilizer (NPK 8-8-8).

\begin{tabular}{|c|c|c|}
\hline Growing media & Compositions & Number of minitubers initiated \\
\hline B1 & $25 \mathrm{AIA}_{3}+2.5 \mathrm{GA}_{3}+0.25 \mathrm{NPK}$ & $0.0 \pm 0.0 \mathrm{~b}$ \\
\hline B2 & $25 \mathrm{AIA}_{3}+2.5 \mathrm{GA}_{3}+0.5 \mathrm{NPK}$ & $3.0 \pm 0.0 \mathrm{a}$ \\
\hline B3 & $25 \mathrm{AIA}_{3}+2.5 \mathrm{GA}_{3}+0.75 \mathrm{NPK}$ & $1.3 \pm 1.3 \mathrm{ab}$ \\
\hline B4 & $25 \mathrm{AIA}_{3}+5 \mathrm{GA}_{3}+0.25 \mathrm{NPK}$ & $0.0 \pm 0.0 \mathrm{~b}$ \\
\hline B5 & $25 \mathrm{AIA}_{3}+5 \mathrm{GA}_{3}+0.5 \mathrm{NPK}$ & $0.0 \pm 0.0 \mathrm{~b}$ \\
\hline B6 & $25 \mathrm{AIA}_{3}+5 \mathrm{GA}_{3}+0.75 \mathrm{NPK}$ & $2.0 \pm 0.5 \mathrm{ab}$ \\
\hline B7 & $25 \mathrm{AIA}_{3}+7.5 \mathrm{GA}_{3}+0.25 \mathrm{NPK}$ & $0.0 \pm 0.0 \mathrm{~b}$ \\
\hline B8 & $25 \mathrm{AIA}_{3}+7.5 \mathrm{GA}_{3}+0.5 \mathrm{NPK}$ & $1.3 \pm 1.3 \mathrm{ab}$ \\
\hline B9 & $25 \mathrm{AIA}_{3}+7.5 \mathrm{GA}_{3}+0.75 \mathrm{NPK}$ & $03 \pm 0.3 b$ \\
\hline B10 & $50 \mathrm{AIA}_{3}+2.5 \mathrm{GA}_{3}+0.25 \mathrm{NPK}$ & $0.0 \pm 0.0 \mathrm{~b}$ \\
\hline B11 & $50 \mathrm{AIA}_{3}+2.5 \mathrm{GA}_{3}+0.5 \mathrm{NPK}$ & $1.6 \pm 0.8 \mathrm{ab}$ \\
\hline B12 & $50 \mathrm{AIA}_{3}+2.5 \mathrm{GA}_{3}+0.75 \mathrm{NPK}$ & $0.0 \pm 0.0 \mathrm{~b}$ \\
\hline B13 & $50 \mathrm{AIA}_{3}+5 \mathrm{GA}_{3}+0.25 \mathrm{NPK}$ & $1.0 \pm 0.0 \mathrm{ab}$ \\
\hline B14 & $50 \mathrm{AIA}_{3}+5 \mathrm{GA}_{3}+0.5 \mathrm{NPK}$ & $1.0+0.0 \mathrm{ab}$ \\
\hline B15 & $50 \mathrm{AIA}_{3}+5 \mathrm{GA}_{3}+0.75 \mathrm{NPK}$ & $0.3 \pm 0.3 b$ \\
\hline B16 & $50 \mathrm{AIA}_{3}+7.5 \mathrm{GA}_{3}+0.25 \mathrm{NPK}$ & $0.5 \pm 0.5 b$ \\
\hline B17 & $50 \mathrm{AIA}_{3}+7.5 \mathrm{GA}_{3}+0.5 \mathrm{NPK}$ & $0.3 \pm 0.3 b$ \\
\hline B18 & $50 \mathrm{AIA}_{3}+7.5 \mathrm{GA}_{3}+0.75 \mathrm{NPK}$ & $0.0 \pm 0.0 \mathrm{~b}$ \\
\hline B19 & $75 \mathrm{AIA}_{3}+2.5 \mathrm{GA}_{3}+0.25 \mathrm{NPK}$ & $0.6 \pm 0.3 \mathrm{ab}$ \\
\hline B20 & $75 \mathrm{AIA}_{3}+2.5 \mathrm{GA}_{3}+0.5 \mathrm{NPK}$ & $0.6 \pm 0.3 b$ \\
\hline B21 & $75 \mathrm{AIA}_{3}+2.5 \mathrm{GA}_{3}+0.75 \mathrm{NPK}$ & $0.6 \pm 0.3 b$ \\
\hline B22 & $75 \mathrm{AIA}_{3}+5 \mathrm{GA}_{3}+0.25 \mathrm{NPK}$ & $1.3 \pm 0.6 \mathrm{ab}$ \\
\hline B23 & $75 \mathrm{AIA}_{3}+5 \mathrm{GA}_{3}+0.5 \mathrm{NPK}$ & $0.0 \pm 0.0 \mathrm{~b}$ \\
\hline B24 & $75 \mathrm{AIA}_{3}+5 \mathrm{GA}_{3}+0.75 \mathrm{NPK}$ & $1.0 \pm 0.0 \mathrm{ab}$ \\
\hline B25 & $75 \mathrm{AIA}_{3}+7.5 \mathrm{GA}_{3}+0.25 \mathrm{NPK}$ & $1.0 \pm 0.0 \mathrm{ab}$ \\
\hline B26 & $75 \mathrm{AIA}_{3}+7.5 \mathrm{GA}_{3}+0.5 \mathrm{NPK}$ & $0.3 \pm 0.3 \mathrm{ab}$ \\
\hline B27 & $75 \mathrm{AIA}_{3}+7.5 \mathrm{GA}_{3}+0.75 \mathrm{NPK}$ & $1.0 \pm 0.0 \mathrm{ab}$ \\
\hline Control & water & $0.0 \pm 0.0 \mathrm{~b}$ \\
\hline$P$-value & & 0.003 \\
\hline
\end{tabular}

Minitubers numbers means followed by the same letter in a column are not significantly different at a probability threshold of $5 \%$, according to the Newman-Keuls mean comparison test. 


\section{Discussion}

Among all the growing media tested, the best survival rates of Dioscorea rotundata vine cuttings were obtained in media containing 0.25\% NPK 8-8-8 (100\%), 25 ppm $\mathrm{AIA}_{3}$ (93.3\%), 25 ppm $\mathrm{AIA}_{3}+5$ ppm GA $+0.5 \%$ NPK (66.6\%) and 2.5 ppm $\mathrm{GA}_{3}(60 \%)$. It appears that the survival rates in media containing $0.25 \%$ NPK 8-8-8 and 25 ppm $\mathrm{AIA}_{3}$ respectively are higher than those obtained by Igwilo (2003) [35] and Dibi et al. (2014) [25] on solid media consisting of coarse construction sand and carbonized rice husks. Indeed, these authors reported survival rates of $71 \%$ and $68 \%$ respectively. In addition, $\mathrm{AIA}_{3}$ favoured root development in $D$. rotundata vine cuttings. Indole- 3 acetic acid $\left(\mathrm{AIA}_{3}\right)$ is an auxin which is a plant growth hormone essential for plant development. Also known as cuttings hormone, auxin acts at a high concentration (between 10-8 and 10-3 $\mathrm{g} \cdot \mathrm{L}^{-1}$ ) on rhizogenesis, promoting the appearance of roots on cuttings [36]. The liquid growing medium containing mineral elements such as nitrogen $(\mathrm{N})$, phosphorus $(\mathrm{P})$ and potassium $(\mathrm{K})$ at a rate of $0.25 \%$ favored the survival of vine cuttings of Dioscorea rotundata. In fact, the positive action of mineral elements on the development of yam vine cuttings has been reported by several authors. According to Otoo et al. (2016) [22], in general, improving the nutritional status of mother plants through nutrient supplementation (NPK 15-25-8) before cutting vines has improved survival rates by more than $16 \%$ and ensures good subsequent development of minitubers. It has also been found that spraying urea on vine cuttings of Dioscorea alata facilitates rooting, increases the size of the minitubers and increases the number of roots per cut; but the survival rate decreases with increasing urea concentration [32]. The average survival rate of vine cuttings in the growing medium containing 2.5 ppm $\mathrm{GA}_{3}(60 \%)$ is similar to that obtained by Behera et al. (2009) [32]. These authors obtained survival rates of $60.02 \%$ for Dioscorea alata vine cuttings when dipped in a solution containing 10 ppm $\mathrm{GA}_{3}$ followed by NPK (100-100-100) on a solid medium consisting of a mixture of sand and cow dung.

The rooting is an essential parameter in the management of cuttings. It is observed 15 days to 3 weeks on average after transplanting vine cuttings of the species D. rotundata and D. cayenensis [37]. This is confirmed by Ayankanmi et al. (2010) [38] who found the formation of roots of vine cuttings from two clones of $D$. rotundata three weeks after transplanting onto a medium containing sand. In addition, Igwilo (2003) [35] reported that after 14 days, cuttings of the Obiaoturugo variety ( $D$. rotundata) showed a high rooting rate. In our study, the highest mean root number was recorded with growing media containing $0.25 \% \mathrm{NPK}$ 8-8-8 (20.3), 25 ppm $\mathrm{AIA}_{3}$ (17.7) and mixed media $25 \mathrm{ppm} \mathrm{AIA}_{3}+5 \mathrm{ppm} \mathrm{GA}_{3}+$ $0.5 \%$ NPK (16.5). These environments favored the increase in the number of roots from the 21 st day to the 35 th day. These average numbers of roots of cuttings are similar to those obtained by other authors. Work by Acha et al. (2004) [28] showed that auxin $\left(\mathrm{AIA}_{3}\right)$ induced an increase in the number of roots of vine cuttings of 10 cultivars of $D$. rotundata from 15 to 30 days after transplant- 
ing. It induces the formation of new roots by overcoming root apical dominance resulting from the cytokinin effect [39]. Behera et al. (2009) [32] showed that treatment with $2 \%$ urea increased the number of roots per cut $(38.16 \%)$ on the 20th day after transplanting. The results obtained in our study corroborate those of Igwilo (2003) [35]. According to these authors, the use of a hormonal solution

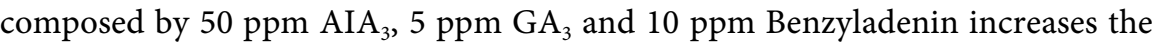
number of roots per vine cuttings of $D$. rotundata. However, the average number of roots of cuttings in $\mathrm{GA}_{3}$-based growing media would be lower than that of the control because the concentrations of $\mathrm{GA}_{3}$ used would appear low to induce an increase in the number or growth of roots. However, the root numbers obtained with $2.5 \mathrm{ppm}$ gibberellic acid are higher than those obtained by Behera et al. (2009) [32] who found that with $1 \mathrm{ppm} \mathrm{GA}_{3}$, the root number per cut can be improved.

The average numbers of minitubers initiated by vine cuttings in the different growing media at $25 \mathrm{ppm} \mathrm{AIA}_{3}, 0.25 \% \mathrm{NPK} 8-8-8$ and the medium containing $25 \mathrm{ppm} \mathrm{AIA}+5 \mathrm{ppm} \mathrm{GA}{ }_{3}+0.5 \%$ NPK $8-8-8$ are $4.6 \pm 0.3 ; 5.0 \pm 0.0$ and $3.3 \pm$ 0.0 respectively. These numbers of minitubers obtained are higher than those reported by Dibi et al. (2014) [25] which were $1.03 \pm 0.3$ and $1.73 \pm 0.86$. Ayankanmi et al. (2010) [38] also obtained poorer results on a rice husk-based growing medium with 0.6 and 0.7 per cut. These differences could be due to the types of media used. The nutrient richness of the medium, its texture and structure influence the formation and development of minitubers [22]. In this study, liquid media were fortified with growth hormones and nutrients, while most authors used solid media based on soil and carbonized rice husks. $\mathrm{GA}_{3}$ growing media produced very little or no minitubers. No significant differences were observed between the numbers of minitubers initiated by cuttings in $\mathrm{GA}_{3}$. Our results are in line with those of Kefi et al. (1995) [40] who reported that gibberellic acid inhibits tuberization in yams. This is confirmed by Behera et al. (2009) [32] who found no significant difference between the numbers of minitubers initiated by vine cuttings treated with different concentrations of gibberellic acid.

The nature and age of the mother plants of the cuttings used could also explain the differences in results observed from one experimenter to another [24]. In this study, vine cuttings were collected from seedlings of 5-month-old grown in a screen house. Other authors have used vitro-plants as mother plants or yam plants grown in the field, whose age varied from 2 to 5 months [22] [35] [38].

\section{Conclusion}

The growing media used in this work produced average survival rates of Dioscorea rotundata vine cuttings between $60 \%$ and $100 \%$ and average root numbers between 5.3 and 17.7. Growing medium containing $0.25 \%$ NPK 8-8-8 has been identified as the one that allows better survival rate, root emission and minituber production by yam vine cuttings. As this nutrient compound is cheaper and more accessible, it is possible to improve the survival rate and rooting of vine 
cuttings that will allow the production of yam seeds without the use of tubers. However, for the standardization of this technic for yam vine cuttings, further studies will have to be carried out, including the definition of the stage and conditions for transplanting vine cuttings from the nursery room to the field.

\section{Acknowledgements}

The authors thank the National Centre for Agronomic Research (CNRA-Côte d'Ivoire) for facilities to operate the research. They are also thankful to Bill and Melinda Gates Foundation who funded this study through "AfricaYam Project". CNRA research technicians, involved in the project are acknowledged. They thank International Institute of Tropical Agriculture (IITA) for the partnership.

\section{Conflicts of Interest}

The authors declare no conflicts of interest regarding the publication of this paper.

\section{References}

[1] Bhattacharjee, R., Gedil, M., Sartie, A., Otoo, E., Dumet, D., Kikuno, H. and Asiedu, R. (2011) Dioscorea. In: Kole, C., Ed., Wild Crop Relatives: Genomic and Breeding Resources. Industrial Crops, Springer, Berlin, 71-96.

https://doi.org/10.1007/978-3-642-21102-7_4

[2] Denis, C. (2015) Influence des premiers stades de croissance sur la variabilité du rendement parcellaire de deux espèces d'igname (Dioscorea spp.) cultivées en Afrique de l'Ouest. Sciences agronomiques et écologiques, Thèse de Doctorat de l'Institut des Sciences et Industries du Vivant et de l'Environnement, Paris, 174 p.

[3] Faostat (2019) Food and Agriculture Organization of the United Nations, 2019. Production: Crops. http://faostat.fao.org

[4] Chukwu, G.O. and Ikwelle, M.C. (2000) Yam: Threats to Its Sustainability in Nigeria. In: Palawija News: The CGPRT Centre Newsletter, Vol. 17, the Centre, 20-25.

[5] Asiedu, R. (2003) Yam in West Africa: Production and Collaborative Research. Agronomie Africaine, Numéro Special, 4, 173-176.

[6] EASA (2009) Evaluation approfondie de la sécurité alimentaire EASA des ménages ruraux en Côte d'Ivoire. Ministère de L'Agriculture, Octobre 2009.

http://www.ins.ci/n/templates/docss/secualim_ruraux.pdf

[7] Ayensu, E.S. and Coursey, D. (1972) Guinea Yams. The Botany, Ethnobotany, Use and Possible Future of Yams in West Africa. Economy and Botany, 26, 301-318. https://doi.org/10.1007/BF02860700

[8] Doumbia, S., Touré, M. and Mahyao, A. (2006) Commercialisation de l'igname en Côte d'Ivoire: État actuel et perspectives d'évolution. Cahiers Agricultures, 15, 273-277.

[9] Doumbia, S., Koko, L. and Aman, S. (2014) L'Introduction et la diffusion de la variété d'igname $\mathrm{C} 18$ en région centre de Cote d'Ivoire. Journal of Applied Biosciences, 80, 7121-7130. https://doi.org/10.4314/jab.v80i1.2

[10] Craufurd, P., Battey, N., Ile, E. and Asiedu, R. (2006) Phases of Dormancy in Yam Tubers (Dioscorea rotundata). Annals of Botany, 97, 497-504. https://doi.org/10.1093/aob/mcl002 
[11] Aighewi, B.A., Asiedu, R., Maroya, N. and Balogun, M. (2015) Propagation Methods to Raise the Production of Yam (Dioscorea rotundata Poir). Food Security, 7, 823-834. https://doi.org/10.1007/s12571-015-0481-6

[12] Dibi, K.E.B., Kouakou, A.M., Camara, B., N’zué, B. and Zohouri, G.P. (2016) Inventaire des méthodes de production de semenceaux d'igname (Dioscorea spp): Une revue de la littérature. Journal of Animal \& Plant Sciences, 29, 4496-4514. http://www.m.elewa.org/JAPS/2016/29.1/1.Dibi.pdf

[13] Hahn, S.K. (1995) Yams: Dioscorea spp. (Dioscoreaceae). In: Smartt, J. and Simmonds, N.W., Eds., Evolution of Crop Plants, Longman Scientific and Technical, Harlow, 112-120.

[14] Okoli, O.O. and Akoroda, M.O. (1995) Providing Seed Tubers for the Production of Food Yams. African Journal of Root and Tuber Crops, 1, 1-6.

[15] Hinvi, J.C. and Nonfon, R. (2000) La production et la commercialisation des semenceaux d'igname à Ouaké (Bénin): Une nécessité de plus en plus incontournable. In: Dans Ebet, A.W. and Djinandou, I.K., Eds., L'igname et la pomme de terre en Afrique de L'Ouest, Actes de séminaire, WASDU, Accra, 81-89.

[16] Shiwachi, H., Kikuno, H. and Asiedu, R. (2005) Micro Tuber Production Using Yam (D. rotundata) Vines. Tropical Science, 45, 163-169.

https://doi.org/10.1002/ts.22

[17] Ironkwe, A.G., Asiedu, R. and Unamma, R.P. (2007) Adoption of Yam Minisett Technology by Women Farmers in Abia State, Nigeria. Journal of Agriculture and Social Research, 7, 95-105. https://doi.org/10.4314/jasr.v7i2.2863

[18] Nweke, F.I., Ugwu, B.O., Asadu, C.L.A. and Ay, P. (1991) Production Cost in the Yam Based Cropping Systems of Southeastern Nigeria. RCPM Research Monograph, No. 6. International Institute of Tropical Agriculture, Ibadan, 29 p.

[19] Manyong, V.M., Asiedu, R. and Olaniyan, G.O. (2001) Farmers' Perception of, and Actions on, Resource Management Constraints in the Yam Based Systems of Western Nigeria. Root Crops in the 21 st Century, Proceedings of the 7 th Triennial Symposium of the International Society for Tropical Root Crops-Africa Branch, Cotonou, 11-17 October 1998, 156-167.

[20] Aighewi, B.A., Akoroda, M.O. and Asiedu, R. (2002) Seed Yam (D. rotundata, Poir) Production, Storage and Quality in Selected Yam Zones of Nigeria. African Journal of Root and Tuber Crops, 5, 20-23.

[21] Alvarez, M.N. and Hahn, S.K. (1984) Seed Yam Production. Tropical Root Crops. Production and Uses in Africa, Proceedings of 2 nd Triennial Symposium of ISTRC-AB, Ottawa, 129-132.

[22] Otoo, E., Anyakanmi, T.G., Kikuno, H. and Asiedu, R. (2016) In Vivo Yam (Dioscorea spp.) Vine Multiplication Technique: The Plausible Solution to Seed Yam Generation Menace. Journal of Agricultural Science, 8, 76-86. https://doi.org/10.5539/jas.v8n2p88

[23] Dao, D. (2003) Transfert de technologie de conservation en milieu rural et étude économique de la filière igname dans un bassin de production au nord de la Côte d'Ivoire, cas de Dikodougou. Thèse de Doctorat unique, Université de Cocody, Abidjan, $136 \mathrm{p}$.

[24] Kikuno, H., Matsumoto, R., Shiwachi, H., Youohara, H. and Asiedu, R. (2007) Comparative Effects of Explants Sources and Age of Plant on Rooting, Shooting and Tuber Formation of Vine Cutting of Yams. Japanese Journal of Tropical Agriculture, 51, 71-72.

[25] Dibi, K., Kouakou, A.M., Yéo, T.J., Fofana, I., N’Zué, B. and Brou, Y.C. (2014) Ef- 
fects of Planting Modes on Yam (Dioscorea rotundata, Poir and Dioscorea alata L.) Vine Cuttings for Mini Tubers Production. International Journal of Sciences, 3, 1-8. https://www.ijsciences.com/pub/article/578

[26] Gbadamosi, A.E., Ajayi, A.T. and Osekita, O.S. (2019) Vine Cutting Propagation in Four Varieties of Yam (Dioscorea Species) Using Different Planting Media. Ife Journal of Science, 21, 441-449. https://doi.org/10.4314/ijs.v21i2.17

[27] Bellefontaine, R., Meunier, Q., Ichaou, A., Morin, A., Mapongmetsem, P.M., Belem, B., Azihou, F., Houngnon, A. and Abdourhamane, H. (2018) La régénération par graines et Par multiplication végétative à faible coût (drageons et boutures de segments de racine). CIRAD Montpellier, $463 \mathrm{p}$.

https://agritrop.cirad.fr/587606/1/ID587606.pdf

[28] Acha, I.A., Shiwachi, H., Asiedu, R. and Akoroda, M.O. (2004) Effect of Auxins on Root Development in Yam (Dioscorea rotundata) Vine. Tropical Science, 44, 80-84. https://doi.org/10.1002/ts.140

[29] Kikuno, H., Muamba, K., Shiwachi, H., Micho, O. and Asiedu, R. (2006) Minituber Production of Yam (D. rotundata) Using Vines. Japanese Journal of Tropical Agriculture, 50, 1-3.

[30] Agele, S.O., Ayankanmi, T.G. and Kikuno, H. (2010) Effects of Synthetic Hormone Substitutes and Genotypes on Rooting and Mini Tuber Production of Vines Cuttings Obtained from White Yam (Dioscorea rotundata, Poir). African Journal of Biotechnology, 9, 4714-4724.

[31] Uyoh, E.A., Ita, E.E., Essien, M., Ewona, E.A.F. and Binang, M. (2016) Effect of Synthetic Hormone Substitutes on Rooting of Vine Cuttings in Water Yam (Dioscorea alata L.). American Journal of Plant Sciences, 7, 1372-1379. https://doi.org/10.4236/ajps.2016.79130

[32] Behera, K., Debashrita, P. and Sahoo, S. (2009) Effect of $\mathrm{GA}_{3}$ and Urea Treatments on Improvement of Microtuber Production and Productivity Material in Greater Yam (Dioscorea alata L.). Notulae Botanicae Horti Agrobotanici, 37, 81-84.

[33] Akassimadou, E.F. and Yao-Kouamé, A. (2014) Caractéristiques morpho-pédologiques et potentiels d'un sol de bas-fond secondaire développé sur granito-gneiss en région de savane guinéenne (Centre de la Côte d'Ivoire). Journal of Applied Biosciences, 79, 6968-6982. https://doi.org/10.4314/jab.v79i1.17

[34] Behera, K., Sahoo, S., Trinanth, M. and Debashrita, P. (2009) Response of Vine Cuttings to Rooting in Different Months in Three Dioscorea Species. Nature and Science, 7, 48-51.

[35] Igwilo, N. (2003) Presence of Axillary Bud and Application of Plant Growth Hormones on Rooting and Tuberization of Yam (Dioscorea spp) Vine Cuttings. Global Journal of Agricultural Sciences, 2, 128-130. https://doi.org/10.4314/gjass.v2i2.2222

[36] Madder, A., Devreese, B., Lusching, C., Friml, J. and Hilson, P. (2012) Secretory Peptides Regulate Auxin Carrier Turnover during Plant Gravitropic Responses. Developmental Cell, 22, 678-685. https://doi.org/10.1016/j.devcel.2012.02.002

[37] Buffard, M. and Touré, B. (1982) Multiplication des végétative par bouturage de cultivars appartenant au complexe Dioscorea cayenensis-rotundata. Fonds documentaire, ORSTOM, 235-249.

[38] Ayankami, T., Agele, S. and Kikuno, H. (2010) Effects of Synthetic Hormone Substitutes and Genotypes on Rooting and Mini Tuber Production of Vines Obtained from White Yam (Dioscorea rotundata, Poir). African Journal of Biotechnology, 9 , 4714-4724.

[39] Antonio, G. and Juan, C. (1996) Les hormones végétales. Pour la Science, 228, 
42-50.

[40] Kefi, S., Read, P., Pavalista, A. and Kachman, S. (1995) The Effect of Different Concentration of Gibberellic Acid $\left(\mathrm{GA}_{3}\right)$ and Kinetin on in Vitro Tuberization of Potato (Solanum tuberosum L.). Horticultural Science, 30, 752-758.

https://doi.org/10.21273/HORTSCI.30.4.752C 